\title{
A New Method in Uterine Cervical Fibroma: Case Report
}

\section{A R T I C L E I N F O}

\section{Article Type}

Case Report

\section{Authors}

Amini A.* $M D$

Mirfendereski A. ${ }^{1} M D$

\section{How to cite this article} Amini A, Mirfendereski A. A New Method in Uterine Cervical Fibroma: Case Report. Sarem Journal of Reproductive Medicine. 2017 $1(3): 137-139$
*Sarem Fertility \& Infertility Research Center (SAFIR), Sarem Women's Hospital, Tehran, Iran ${ }^{1}$ Sarem Fertility \& Infertility Research Center (SAFIR), Sarem Women's Hospital, Tehran, Iran

\section{Correspondence}

Address: Sarem Women's Hospital, Basij Square, Phase 3, Ekbatan Town, Tehran, Iran. Postal Code: 1396956111

Phone: +98 (21) 44670888

Fax: +98 (21) 44670432

aliaminimd@yahoo.com

\section{Article History}

Received: March 10, 2016

Accepted: June 14, 2016

ePublished: August 15, 2017

\section{A B S T R A C T}

Patient Information Uterine leiomyomas are the most common pelvic tumors in women. The patient is 26 year old virgin woman, who had come to Sarem Hospital due to severe bleeding. In the studies, cervical fibrosis was detected in the uterus, which was associated with anemia and severe bleeding, and the removal of fibroma was necessary. Cervical fibrosis is surgically removed through the vaginal canal, but the patient, due to virginity, was reluctant to undergo surgery through the vaginal canal. Therefore, the decision was made to perform this surgery through abdominal myomectomy. The patient was discharged from the hospital 2 days after surgery with a good general condition and satisfaction with the health of the virginity.

Conclusion In Islamic countries such as Iran, considering the culture of the general public, the virginity is very important. In this particular case, due to the request of his virginity and its importance for the family, surgery through abdominal myomectomy was recommended. Although the surgical procedure is followed by scarring of abdominal surgery and postoperative pain, but the result is the same as the result of the surgery through the vaginal canal.

Keywords Leiomyoma; Fibroma; Uterus; Surgical Procedures, Operative 


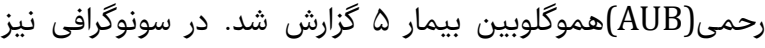

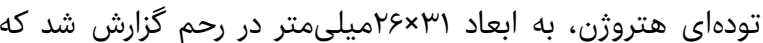

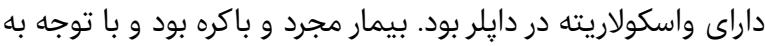

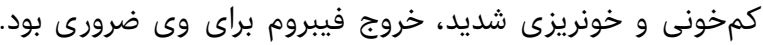

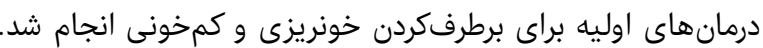

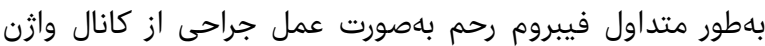

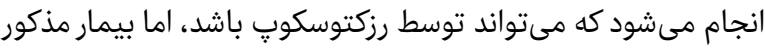

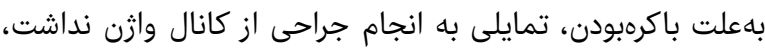

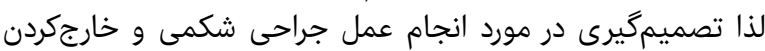

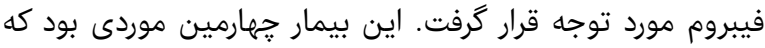

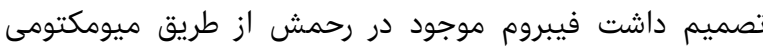

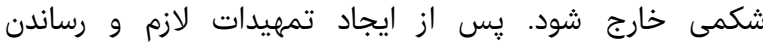

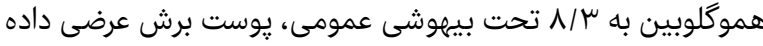

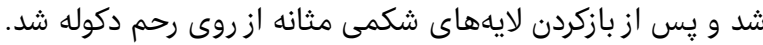

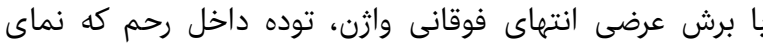

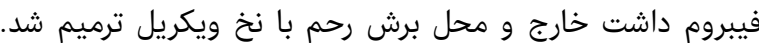

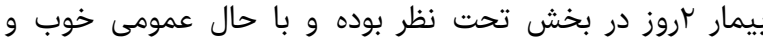

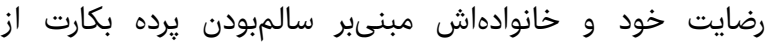
بيمارستان مرخص شد (شكلهاى (و r).

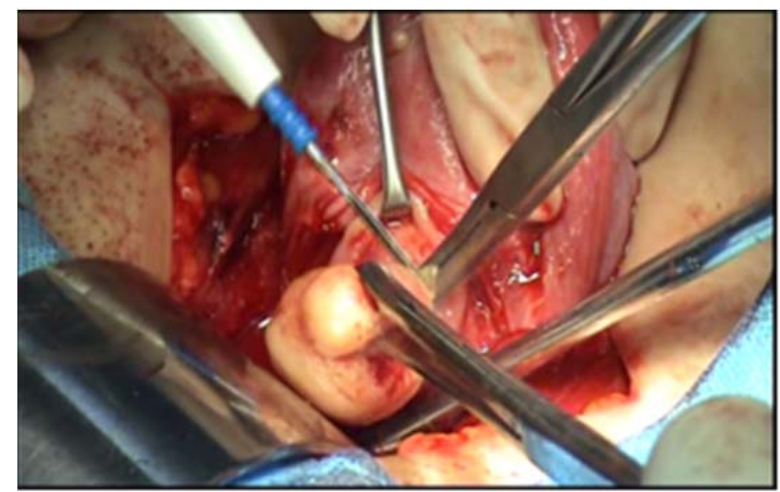

شكل () برش عرضى در انتهاى فوقانى واثن و خارجكردن توده از اين طريق

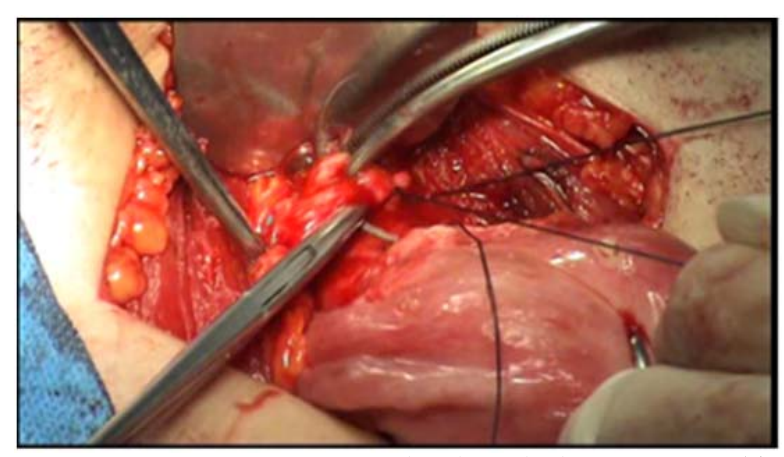

شكل r) دوختن برش انتهاى فوقانى واثن

بحث

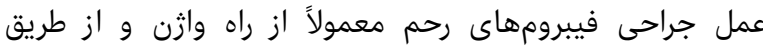

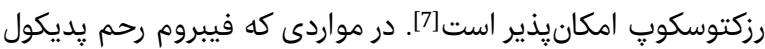

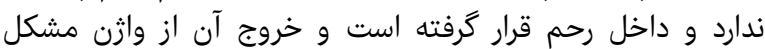

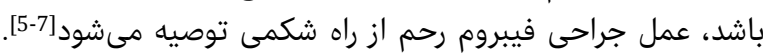

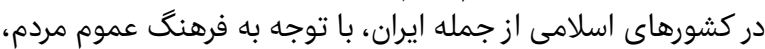

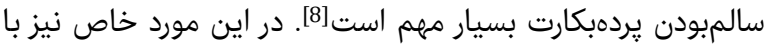

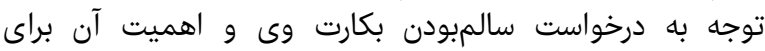

ارايه روش جديد در عمل جراحى فيبروم سرويكال

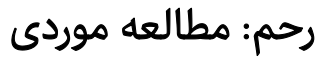

MD " على امينى

مركز تحقيقات بارورى و نابارورى صارم، بيمارستان فوق تخصصى صارم، تهران،

ايران

آتيه ميرفندرسكى إنى

مركز تحقيقات بارورى و نابارورى صارم، بيمارستان فوق تخصصى صارم، تهران، ايران

جكيده

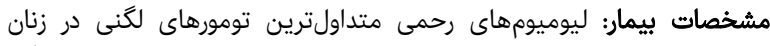

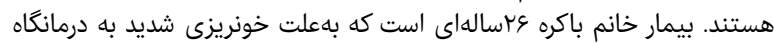

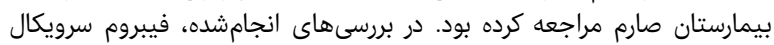

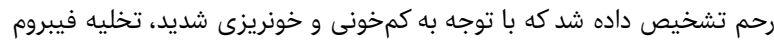

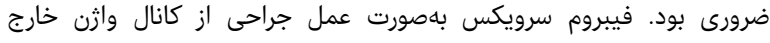

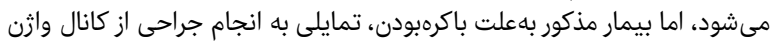

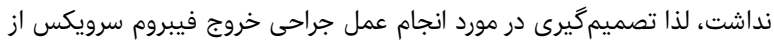

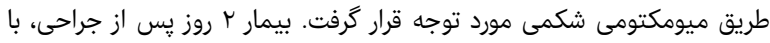

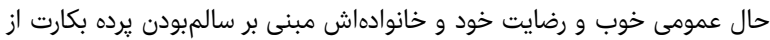

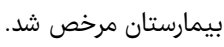

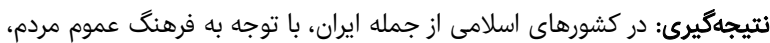

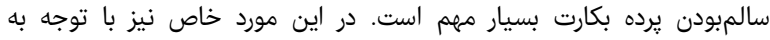

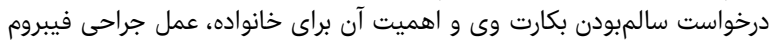

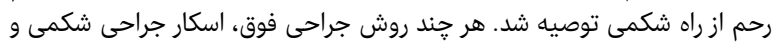

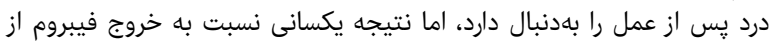
كانال وازينال دارد. كليدوازمها: ليوميوم، فيبروم، رحم، جراحى شكمى

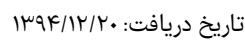

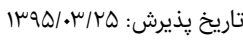
aliaminimd@yahoo.com :نويسنده مسئون:

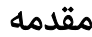

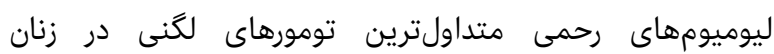

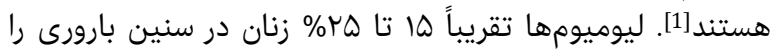

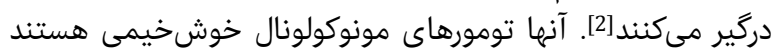

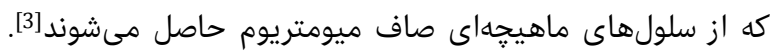

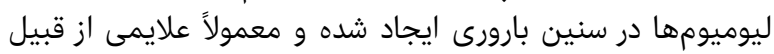

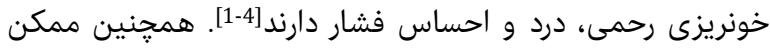

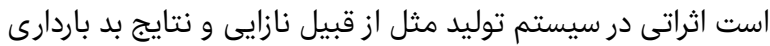

داشته باشند [5].

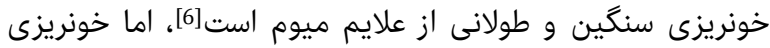

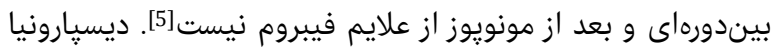

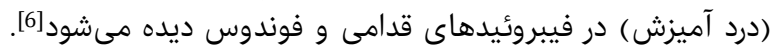

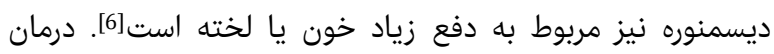

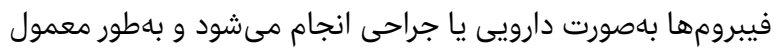

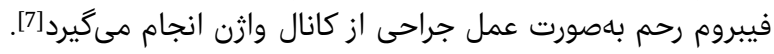

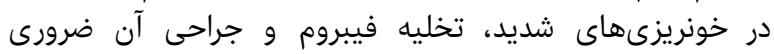

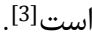

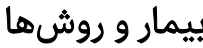

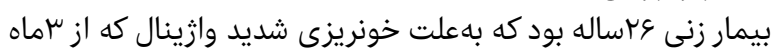

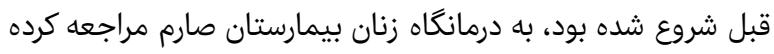

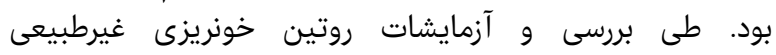




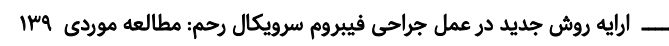

myomectomy. J Minim Invasive Gynecol. 2010;17(3):301-55.

2- Chang WC, Chen SY, Huang SC, Chang DY, Chou LY, Sheu BC. Strategy of cervical myomectomy under laparoscopy. Fertil Steril. 2010;94(7):2710-5.

3- Matsuoka S, Kitade M, Kikuchi I, Kumakiri J, Kuroda K. Strategy of Cervical Myoma under Laparoscopy. J Minim Invasive Gynecol. 2009;16(6 Suppl):S125.

4- Sinha R, Hegde A, Warty N, Mahajan C. Laparoscopic myomectomy: Enucleation of the myoma by morcellation while it is attached to the uterus. J Minim Invasive Gynecol. 2005;12(3):284-9.

5- Shi R. Clinical Analysis of Laparoscopic Myomectomy for Patients with Cervical Myoma. J Minim Invasive Gynecol. 2010;17(6 Supple):S62.

6- Pravin P, Banker M, Munshi N, Bhalla A. Handling Cervical Myomas. J Gynecol Endosc Surg. 2011; 2(1): 302.

7- Songshu X, Min X, Yajun W, Yueran L, Dabao X. Hysteroscopy- and laparoscopy-based diagnosis and treatment of girls with unbroken hymen with an obstructing uterine septum: two case reports. J Med Case Rep. 2014;8:222.

8- Xu DB, Xue M, Cheng CX, Wan Y. Hysteroscopy for the diagnosis and treatment of pathologic changes in the uterine cavity in women with an intact hymen. J Minim Invasive Gynecol. 2006;13(3):222-4.

9- Spitzer RF, Caccia N, Kives S, Allen LM. Hysteroscopic unification of a complete obstructing uterine septum: Case report and review of the literature. Fertil Steril. 2008;90(5): 2016.e17-2016.e20.

10-Kim HS, Kim JW, Kim MK, Chung HH, Lee TS, Jeon YT, et al. A randomized prospective trial of the postoperative quality of life between laparoscopic uterine artery ligation and laparoscopy-assisted vaginal hysterectomy for the treatment of symptomatic uterine fibroids: clinical trial design. Trials. 2009;29;10: 8.

خانواده، عمل جراحى فيبروم رحم از راه شكمى توصيه شد. هر جند

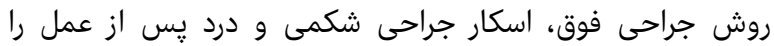

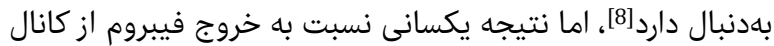

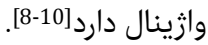

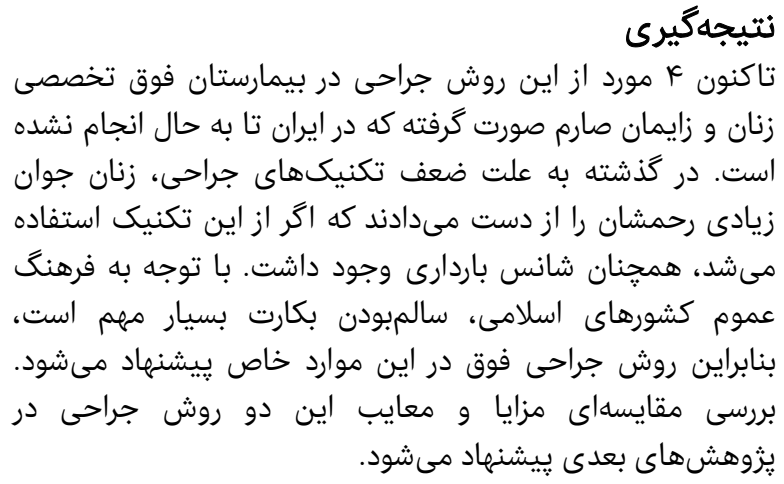

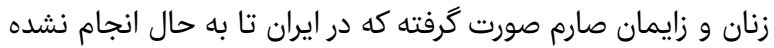

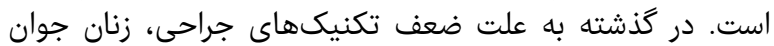

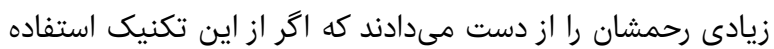

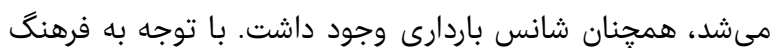

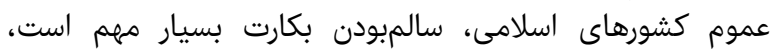

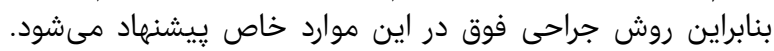

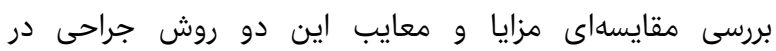

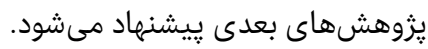

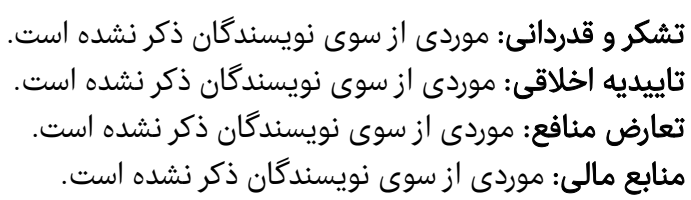

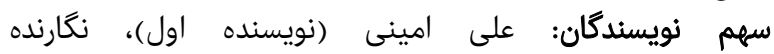

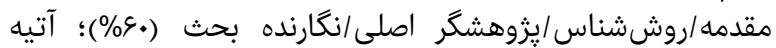

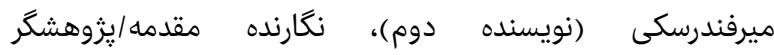

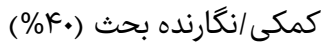

$$
\text { منابع }
$$

1- Matsuoka S, Kikuchi I, Kitade M, Kumakiri J, Kuroda K, Tokita S, et al. Strategy for laparoscopic cervical 